\title{
Rapid In Vitro Plant Regeneration of Black Gram (Vigna mungo L. Hepper) Var. Sarala, an Important Legume Crop
}

\author{
Pradip M. Adlinge $\cdot$ Kailash Chandra Samal • \\ R. V. Kumara Swamy · Gyana Ranjan Rout
}

Received: 23 July 2013/Revised: 11 October 2013/Accepted: 18 November 2013/Published online: 21 December 2013

(C) The Author(s) 2013. This article is published with open access at Springerlink.com

\begin{abstract}
Efficient in vitro regeneration of black gram (Vigna mungo L. Hepper) var. Sarala was achieved through organogenesis using cotyledonary explants excised from 4 days old seedlings on MS medium supplemented with $2.0 \mathrm{mg} / \mathrm{l} \mathrm{BAP}$. Organogenic calli were developed from cotyledonary tissues within 4-6 weeks of culture on MS medium supplemented with $3.0 \mathrm{mg} / \mathrm{l}$ 6-benzylaminopurine (BAP) along with $2.0 \mathrm{mg} / \mathrm{l}$ 1-napthaleneacetic acid (NAA). Shoot bud regeneration was achieved on MS medium supplemented with $2.0 \mathrm{mg} / \mathrm{l} \mathrm{BAP}$ within 3-4 weeks of subculture. The number of shoots per culture varied from 1.12 to 8.75 in different growth media. The cultures incubated initially on dark photoperiod for 2 weeks and subsequently transferred to $16 \mathrm{~h}$ photoperiod showed higher number of shoot bud regeneration. The proliferated shoots were further sub-cultured on similar medium for higher rate of shoot bud regeneration. The elongated shoots were rooted on $1 / 2$ strength MS medium fortified with $0.1-0.5 \mathrm{mg} / \mathrm{l}$ NAA or indole-3-acetic acid (IAA) or indole3-butyric acid (IBA) with $2 \%(\mathrm{w} / \mathrm{v})$ sucrose within 2-3 weeks of culture. The higher percentage of rooting was obtained on $0.1-0.25 \mathrm{mg} / \mathrm{l}$ NAA as compared with IBA or IAA. The rooted plantlets were transferred to soil mixture (soil: sand: vermi-compost, 1:1:1 ratio) and kept in the greenhouse with $85 \%$ humidity. The regenerated plantlets were successfully grown with $75 \%$ survival rate. This protocol can be used for genetic improvement of black gram.
\end{abstract}

P. M. Adlinge - K. C. Samal · R. V. Kumara Swamy •

G. R. Rout $(\square)$

Department of Agricultural Biotechnology, College of

Agriculture, Orissa University of Agriculture and Technology,

Bhubaneswar 751003, India

e-mail: grrout@rediffmail.com
Keywords Vigna mungo - Shoot bud regeneration . Growth regulator $\cdot$ Culture condition

\section{Introduction}

Black gram (Vigna mungo L. Hepper) belonging to family Fabaceae is an important nitrogen fixing, short-duration, tropical pulse crop grown in many parts of India. It is thought to have originated in the Indian subcontinent with maximum diversity in the Western Ghats [1]. Black gram plays an important role in Indian diet as it contains vegetable protein and also other minerals and vitamins. It supplies major share of protein requirement of vegetarian population of the country. Although India is the origin place for many of the Vigna spp. and it is widely cultivated, but the productivity is low. A number of biotic and abiotic stresses are severely affecting the production and productivity of black gram. Thereby, full realization of the yield potential of pulse crops is not achieved yet. So there is a need to increase productivity of black gram by developing new cultivars resistant to biotic and abiotic stresses. Pulses have narrow genetic base, thus in order to widen the genetic base and incorporate desirable character, there is an urgent need to use transgenic technologies for improvement of legume crops. Conventional breeding programs may be valuable, but to utilize molecular methods to introduce the genes for stress-associated mechanisms will give an added advantage for improvement program. For the successful transfer of genes, reliable and efficient in vitro regeneration and transformation protocol is a prerequisite. Grain legumes are comparatively recalcitrant to regeneration and transformation. In grain legumes, tissue culture has been repeatedly described as difficult [2,3]. Regeneration from both organogenesis and somatic embryogenesis 
has been recalcitrant in legume crops [2, 4-8]. Scanty information are available on in vitro regeneration of black gram, but the reproducibility of these results is very meagre $[9,10]$. The present investigation was to establish efficient protocol on in vitro shoot organogenesis from cotyledonary explants of V. mungo L. Hepper.

\section{Material and Methods}

Induction of Callus

The seeds of black gram (V. mungo L. Hepper) cv. Sarala were collected from Regional Research and Technology Transfer Station, Orissa University of Agriculture and Technology, Berhampur, Ganjam, Odisha. The seeds were surface sterilized with $70 \%$ ethanol $(\mathrm{v} / \mathrm{v})$ for $1 \mathrm{~min}$ followed by washing twice with sterilized distilled water for $2-3$ times. Seeds were treated with $0.2 \% \mathrm{HgCl}_{2}$ (w/v) solution for $3 \mathrm{~min}$ followed by thorough washing for 4 to 5 times with sterile distilled water to remove all the traces of $\mathrm{HgCl}_{2}$ and blot dried on sterilized filter paper. Sterilized seeds were germinated under aseptic conditions on MS [11] medium without growth regulators. The cotyledonary segments were excised from 4-days old seedling (Fig. 1A) and cultured in test tubes $(25 \times 150 \mathrm{~mm})$ on various concentrations $(0,1.0,1.5,2.0,3.0$ and $4.0 \mathrm{mg} / \mathrm{l})$ of 6-benzylaminopurine (BAP) or kinetin alone or in combination with either indole-3-acetic acid (IAA) or 1-napthaleneacetic acid (NAA) $(0.1,0.25,0.5,1.0,1.5$ and $2.0 \mathrm{mg} / \mathrm{l})$ and $25-50 \mathrm{mg} / \mathrm{l}$ adenine sulfate (Ads) for induction of callus and shoot bud regeneration. The cultures were incubated either in dark for 2 weeks and subsequently transferred to $16 \mathrm{~h}$ photoperiod or continuous $16 \mathrm{~h}$ photoperiod with $25 \pm 2{ }^{\circ} \mathrm{C}$ for regeneration. The $\mathrm{pH}$ of the medium was adjusted to 5.7 before adding of agar-agar. The subculture was made at every 4 weeks interval in similar medium. The culture medium was autoclaved at $121{ }^{\circ} \mathrm{C}$ at $17 \mathrm{~kg} / \mathrm{cm}^{2}$ pressure for $15 \mathrm{~min}$. The data was taken at every 2-3 weeks interval with regard to percentage of callus formation, regeneration frequency, number of shoot buds per culture and shoot elongation. The experiment was conducted thrice with 15 replications per treatment.

\section{Induction of Rooting and Transplantation}

The elongated shoots (3-4 cm long) were excised and transferred to MS semisolid medium as well as liquid medium fortified with various concentrations of IAA or indole-3-butyric acid (IBA) or NAA (0.1, 0.25 and $0.5 \mathrm{mg} / \mathrm{l})$ alone or in combination of IBA and NAA with $2 \%(\mathrm{w} / \mathrm{v})$ sucrose for induction of rooting. The cultures were incubated in $25 \pm 2{ }^{\circ} \mathrm{C}$ with $16 \mathrm{~h}$ photoperiod with 3,000 lux intensity. Rooted plantlets were transferred to earthen pots containing soil: sand: vermi-compost (1:1:1) mixture for hardening under greenhouse with $85 \%$ humidity. The data was taken at 3 weeks interval with regard to percentage of rooting, days to rooting and types of root.

All the experiments were carried out in the laboratory under completely randomized design (CRD). The data were analyzed statistically by the Duncan's multiple range test [12]. Means followed by the same letter within a column were not significantly different at $P<0.05$.

\section{Results and Discussion}

In vitro shoot bud regeneration from cotyledonary tissues of black gram was achieved on MS medium supplemented with various concentrations of BAP or Kn supplemented with NAA or IAA. Culture medium without growth regulators did not show any positive effect on organogenic callus formation as well as shoot bud regeneration. Among the two cytokinin tested, BAP showed higher rate of shoot bud regeneration as compared with kinetin. BAP in combination with NAA also enhanced the higher frequency of regeneration as compared to BAP + IBA. The inclusion of auxin in the culture medium showed the higher rate of shoot organogenesis. With increase of BAP concentrations (more than $4.0 \mathrm{mg} / \mathrm{l}$ ) in the culture medium, the rate of regeneration was reduced. The maximum frequency of regeneration $(68.3 \%)$ was achieved on MS medium supplemented with $2.0 \mathrm{mg} / \mathrm{l} \mathrm{BAP}$ and $1.5 \mathrm{mg} / \mathrm{l} \mathrm{NAA}$ after 8 weeks of culture (Table 1; Fig. 1B). The inclusion of adenine sulphate $(25-50 \mathrm{mg} / \mathrm{l})$ in the culture medium showed the higher rate of shoot bud elongation and regeneration. The culture medium having kinetin (1-2 mg/l) did not show any significant effect on shoot bud regeneration as compared with BAP. Addition of either auxin or adenine sulphate in the medium also did not affect the regeneration frequency. Shoot multiplication and propagation of black gram have also been reported by using various explants by different workers [9, 13-17] with increase of BAP concentration from 2.0 to $3.0 \mathrm{mg} / \mathrm{l}$, the rate of shoot bud regeneration frequency increased but the shoot growth reduced. Further increase of either BAP or kinetin reduced the frequency of shoot bud regeneration. The cultures initially incubated for 2 weeks in dark and subsequently transferred to $16 \mathrm{~h}$ photoperiod, showed higher rate of shoot multiplication as compared with the cultures incubated in completely $16 \mathrm{~h}$ photoperiod (data not shown). The cytokinin has significant effect on shoot multiplication as reported earlier in other legume crops like chickpea and mung bean [7, 18-20]. In the present study, the maximum (8.75) number of shoot buds/culture was 

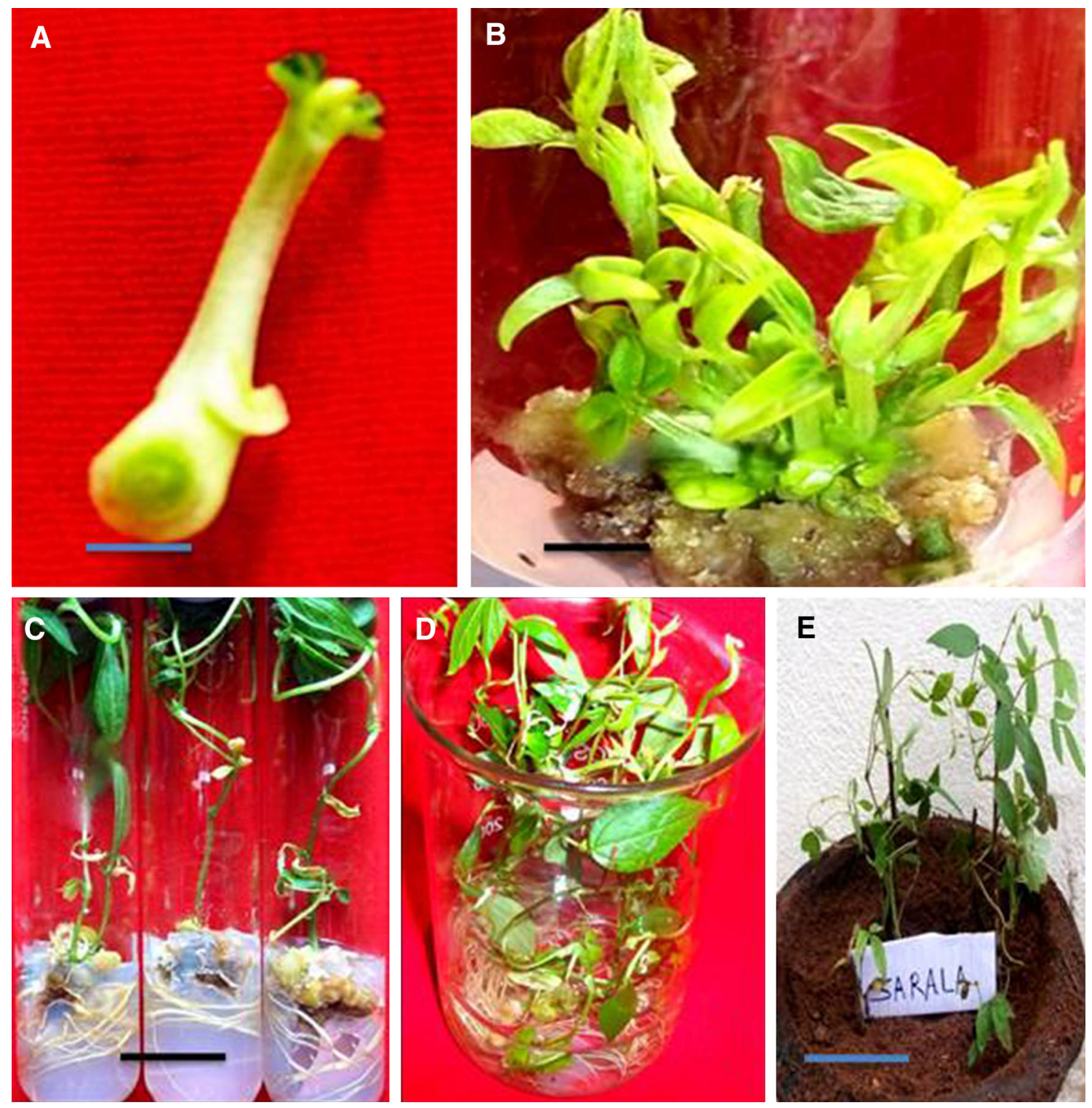

Fig. 1 A Germinated seedling of $V$. mungo grown on MS medium supplemented with $2.0 \mathrm{mg} / \mathrm{l} \mathrm{BAP}$ and $1.5 \mathrm{mg} / \mathrm{l}$ NAA after $4-5$ days of culture (Bar $10 \mathrm{~mm}$ ). B Development of shoot buds from cotyledon derived callus of $V$. mungo grown on MS medium supplemented with $2.0 \mathrm{mg} / \mathrm{l} \mathrm{BAP}$ and $1.5 \mathrm{mg} / \mathrm{l} \mathrm{NAA}$ after 8 weeks

obtained within 8 weeks culture on MS medium supplemented with $2 \mathrm{mg} / \mathrm{l} \mathrm{BAP}+1.5 \mathrm{mg} / \mathrm{l} \mathrm{NAA}+25 \mathrm{mg} / \mathrm{l}$ Ads (Fig. 1B; Table 1). Muruganantham et al. [9] reported that the multiple shoot induction (6 shoot buds/explant) was obtained from axillary shoots on medium having $1.0 \mathrm{mg} / \mathrm{l}$ BAP. Mony et al. [10] reported that the lowering of BAP concentration $(1.0 \mathrm{mg} / \mathrm{l})$ produced maximum number of shoots (9.33) in case of black gram. They had also stated that the increase the BAP concentration in medium resulted in the formation of callus.

For better establishment of plantlets in the field, well developed rooting system is necessary. Elongated healthy of subculture (Bar $80 \mathrm{~mm}$ ). C Proliferation of roots from excised shoots of $V$. mungo grown on $1 / 2$ MS medium supplemented with $0.25 \mathrm{mg} / \mathrm{l} \mathrm{NAA}$ after 8 days of culture $($ Bar $=50 \mathrm{~mm})$. D Rooted plantlets kept in sterile distilled water before transfer to pot. E Rooted plantlets establish in soil with normal growth $(\mathrm{Bar}=1.0 \mathrm{~cm})$

individual shoots $(>4.0 \mathrm{~cm})$ were isolated and cultured on different root induction media (half strength MS medium supplemented with IAA or IBA or NAA) alone as well as in combination for root induction. Root initiation was not achieved on medium without growth regulators. Root initiation developed in half-strength MS medium supplemented with $0.1-0.25 \mathrm{mg} / \mathrm{l}$ NAA or IBA after 8 to 10 days of culture (Fig. 1C). The medium having NAA showed better root formation as compared with IBA (Table 2). The medium having both IBA and NAA resulted in low percentage of rooting and formation of globular callus at the cut end. The percentage of rooting varied from 25.8 to 
Table 1 Effect of plant growth regulators (PGRs) on shoot bud regeneration from cotyledon explants of $V$. mungo var. Sarala after 8 weeks of subculture

\begin{tabular}{|c|c|c|c|c|c|c|}
\hline \multicolumn{5}{|c|}{ MS + growth regulators $(\mathrm{mg} / \mathrm{l})$} & \multirow{2}{*}{$\begin{array}{l}\% \text { of shoot bud } \\
\text { regeneration } \\
\left(\text { mean } \pm \mathrm{SE}^{\mathrm{a}}\right)\end{array}$} & \multirow{2}{*}{$\begin{array}{l}\text { No. of } \\
\text { shoots/culture } \\
\left(\text { mean } \pm \mathrm{SE}^{\mathrm{a}}\right)\end{array}$} \\
\hline $\mathrm{Kn}(\mathrm{mg} / \mathrm{l})$ & BAP (mg/l) & NAA (mg/l) & IAA (mg/l) & Ads (mg/l) & & \\
\hline 0.0 & 0.0 & 0.0 & 0.0 & 0.0 & 0.0 & 0.0 \\
\hline 0.5 & 0.0 & 0.0 & 0.0 & 0.0 & 0.0 & 0.0 \\
\hline 1.0 & 0.0 & 0.0 & 0.0 & 0.0 & $10.5 \pm 0.8 b$ & $1.50 \pm 0.5 \mathrm{~b}$ \\
\hline 1.5 & 0.0 & 0.0 & 0.0 & 0.0 & $18.7 \pm 1.2 \mathrm{e}$ & $1.25 \pm 0.6 \mathrm{a}$ \\
\hline 2.0 & 0.0 & 0.0 & 0.0 & 0.0 & $23.0 \pm 1.4 \mathrm{f}$ & $2.75 \pm 0.7 \mathrm{f}$ \\
\hline 3.0 & 0.0 & 0.0 & 0.0 & 0.0 & $16.2 \pm 1.2 \mathrm{~d}$ & $1.88 \pm 0.4 \mathrm{c}$ \\
\hline 4.0 & 0.0 & 0.0 & 0.0 & 0.0 & $8.4 \pm 0.76^{\mathrm{b}} \mathrm{a}$ & $1.12 \pm 0.5 \mathrm{a}$ \\
\hline 2.0 & 0.0 & 1.0 & 0.0 & 0.0 & $32.4 \pm 1.0 \mathrm{~g}$ & $2.76 \pm 0.5 \mathrm{f}$ \\
\hline 2.0 & 0.0 & 1.5 & 0.0 & 0.0 & $34.5 \pm 1.2 \mathrm{~h}$ & $2.25 \pm 0.5 \mathrm{~d}$ \\
\hline 3.0 & 0.0 & 1.5 & 0.0 & 0.0 & $18.6 \pm 1.4 \mathrm{e}$ & $2.56 \pm 0.3 \mathrm{e}$ \\
\hline 0.0 & 1.0 & 0.0 & 0.0 & 0.0 & $14.6 \pm 0.9 \mathrm{c}$ & $2.13 \pm 0.2 \mathrm{~d}$ \\
\hline 0.0 & 2.0 & 0.0 & 0.0 & 0.0 & $34.2 \pm 1.1 \mathrm{~h}$ & $2.45 \pm 0.5 \mathrm{e}$ \\
\hline 0.0 & 3.0 & 0.0 & 0.0 & 0.0 & $42.8 \pm 1.3 \mathrm{j}$ & $2.56 \pm 0.3 \mathrm{e}$ \\
\hline 0.0 & 4.0 & 0.0 & 0.0 & 0.0 & $36.7 \pm 0.9^{b_{i}}$ & $1.81 \pm 0.4 \mathrm{c}$ \\
\hline 0.0 & 2.0 & 1.5 & 0.0 & 0.0 & $68.3 \pm 1.4 \mathrm{r}$ & $3.32 \pm 0.8 \mathrm{~g}$ \\
\hline 0.0 & 3.0 & 1.5 & 0.0 & 0.0 & $66.6 \pm 1.2 \mathrm{p}$ & $3.54 \pm 0.9 \mathrm{~h}$ \\
\hline 0.0 & 2.0 & 2.0 & 0.0 & 0.0 & $62.8 \pm 1.3 \mathrm{n}$ & $5.85 \pm 0.9 \mathrm{j}$ \\
\hline 0.0 & 3.0 & 2.0 & 0.0 & 0.0 & $54.4 \pm 1.3^{\mathrm{b}} \mathrm{m}$ & $4.21 \pm 0.8 \mathrm{i}$ \\
\hline 0.0 & 2.0 & 1.5 & 0.0 & 25.0 & $72.4 \pm 1.0 \mathrm{~s}$ & $8.75 \pm 1.01$ \\
\hline 0.0 & 2.0 & 1.5 & 0.0 & 50.0 & $67.8 \pm 0.9 \mathrm{q}$ & $6.32 \pm 0.9 \mathrm{k}$ \\
\hline 0.0 & 3.0 & 1.5 & 0.0 & 25.0 & $64.5 \pm 1.2^{\mathrm{b}} \mathrm{o}$ & $6.16 \pm 0.8 \mathrm{k}$ \\
\hline 0.0 & 3.0 & 1.5 & 0.0 & 50.0 & $66.8 \pm 1.5^{\mathrm{b}} \mathrm{p}$ & $6.38 \pm 1.0 \mathrm{k}$ \\
\hline 0.0 & 2.0 & 0.0 & 1.5 & 0.0 & $41.5 \pm 0.8 \mathrm{k}$ & $3.82 \pm 0.6 \mathrm{~h}$ \\
\hline 0.0 & 2.0 & 0.0 & 2.0 & 0.0 & $45.4 \pm 1.31$ & $2.88 \pm 0.7 \mathrm{f}$ \\
\hline
\end{tabular}

Means followed by the same letter within a column were not significantly different at the $5 \%$ level

a 15 replicates/treatment repeated thrice

b Green globular calli

Table 2 Effect of different concentrations of auxins on root induction from excised shoots of $V$. mungo var. Sarala

\begin{tabular}{|c|c|c|c|c|c|}
\hline \multicolumn{3}{|c|}{$1 / 2 \mathrm{MS}+$ growth regulators $(\mathrm{mg} / \mathrm{l})$} & \multirow[t]{2}{*}{ Days to rooting } & \multirow[t]{2}{*}{$\%$ of rooting $\left(\right.$ mean $\pm \mathrm{SE}^{\mathrm{a}}$ ) } & \multirow[t]{2}{*}{ Types of root } \\
\hline IAA $(\mathrm{mg} / \mathrm{l})$ & IBA (mg/l) & NAA (mg/l) & & & \\
\hline 0.0 & 0.0 & 0.0 & 0.0 & 0.0 & - \\
\hline 0.1 & 0.0 & 0.0 & $11-12$ & $25.8 \pm 1.2 \mathrm{a}$ & Short, thick \\
\hline 0.25 & 0.0 & 0.0 & $11-12$ & $30.2 \pm 1.6 \mathrm{~b}$ & Short, thin \\
\hline 0.50 & 0.0 & 0.0 & $13-14^{\mathrm{b}}$ & $32.8 \pm 1.3 \mathrm{~b}^{\mathrm{b}}$ & Short, thick, single \\
\hline 0.0 & 0.1 & 0.0 & 9.0 & $46.2 \pm 2.5 \mathrm{c}$ & Short, thin \\
\hline 0.0 & 0.25 & 0.0 & $9-10$ & $56.8 \pm 2.6 \mathrm{~d}$ & Long, thin, \\
\hline 0.0 & 0.50 & 0.0 & $9-10^{\mathrm{b}}$ & $62.4 \pm 3.2 \mathrm{e}^{\mathrm{b}}$ & Long, thin, single \\
\hline 0.0 & 0.0 & 0.10 & $8-9$ & $67.2 \pm 3.4 \mathrm{f}$ & Long, thin, \\
\hline 0.0 & 0.0 & 0.25 & $8-9$ & $76.6 \pm 2.8 \mathrm{~g}$ & Long, thin, multiple branching \\
\hline 0.0 & 0.0 & 0.50 & $8-9$ & $56.4 \pm 3.2 \mathrm{~d}$ & Long, thin, branching \\
\hline 0.0 & 0.1 & 0.25 & $9-10^{\mathrm{b}}$ & $64.4 \pm 2.7 \mathrm{e}^{\mathrm{b}}$ & Long, thin, branching \\
\hline
\end{tabular}

Means followed by the same letter within a column were not significantly different at the $5 \%$ level

a 15 shoots/treatment repeated thrice

b Globular callusing at the basal end 
$76.6 \%$ depending on growth regulators used. The roots were branched, thin and elongated. However, IBA was effective for root induction as reported by Das et al. [21] and Geetha et al. [17]. Mony et al. [10] found that percentage of rooting was higher in IBA but number of roots per plant was higher in NAA.

\section{Transplantation in Soil}

The rooted plantlets were transferred to distilled water and kept for $72 \mathrm{~h}$ for acclimatization (Fig. 1D). Further, the plantlets were transferred to polythene bag containing soil:sand:vermi-compost (1:1:1) and kept in the greenhouse for 15 days with $85 \%$ relative humidity (RH). After 2 weeks, these plantlets were transferred to poly-house for hardening and final establishment (Fig. 1E). Survival percentage of the transplanted plantlets was 70-75\%. Further, the plantlets grew normally.

Acknowledgments The authors wish to acknowledge to Department of Biotechnology, Ministry of Science and Technology, Government of India to provide fund for student research under PG-HRD program.

Open Access This article is distributed under the terms of the Creative Commons Attribution License which permits any use, distribution, and reproduction in any medium, provided the original author(s) and the source are credited.

\section{References}

1. De Candolle A (1883) In: Laffitte J (ed) Origine des plantes cultivées. G. Bailliere et cie, Paris

2. Chandra A, Pental D (2003) Regeneration and genetic transformation of grain legumes: an overview. Curr Sci 84:381-387

3. Eapen S (2008) Advances in development of transgenic pulse crops. Biotech Adv 26:162-168

4. Ananad RP, Ganapathi A, Vengadesan G, Selvaraj N, Anbazhagan VR, Kulothungan S (2001) Plant regeneration from immature cotyledon derived callus of Vigna ungiculata (L.). Curr Sci 80 : 671-674

5. Senapati SK, Rout GR (2008) Micropropagation of Acacia chundra (Roxb.) DC. Hort Sci (Prague) 35:22-26

6. Shivakumar P, Gnanam IR, Ramakrishnan K, Manickam A (2010) Regeneration of Vigna radiata. Biologia Plant 54(2): 245-251
7. Yadav SK, Sreenu P, Maheswari M, Vanaja M, Venkateswarlu B (2010) Efficient shoot regeneration from double cotyledonary node explants of green gram(Vigna radiata L Wilczek). Indian $\mathbf{J}$ Biotechnol 9:403-407

8. Anwar F, Salem S, Alghamdi, Megahe H, Siddique KHM (2011) An efficient in vitro regeneration protocol for faba bean (Vicia faba L.). J Med Plants Res 5:6460-6467

9. Muruganantham M, Ganapathi A, Amutha S, Vengadesan G, Selvaraj N (2005) Shoot regeneration from immature cotyledonary nodes in black gram (Vigna mungo (L.) Hepper). Indian J Biotechnol 4:551-555

10. Mony SA, Haque MdS, Alam MdM, Hasanuzzaman M, Nahar K (2010) Regeneration of black gram (Vigno mungo L.) on changes of hormonal condition. Not Bot Hort Agrobot Cluji, 38(3):140145

11. Murashige T, Skoog F (1962) A revised medium for rapid growth and bioassays with tobacco tissue cultures. Physiol Plant 15:473-497

12. Duncan DB (1955) Multiple range and multiple F-tests. Biometrics $11: 1-42$

13. Goel S, Mudgal AK, Gupta SC (1983) Development of plants from in vitro cultured shoot tips of Vigna mungo and $V$. radiata. Trop Plant Sci Res 1:31-33

14. Gill R, Eapen S, Rao PS (1987) Tissue culture studies in moth bean-factors influencing plant regeneration from seed explants of cultivars. Proc Indian Acad Sci 96:55-61

15. Gill R, Eapen S, Rao PS (1987) Morphogenetic studies of cultured cotyledons of urdbean (Vigna mungo L. Hepper). J Plant Physiol 130:1-5

16. Das DK, Prakash NS, Sarin NB (1998) An efficient regeneration system of black gram (Vigna mungo L.) through organogenesis. Plant Sci 134:199-206

17. Geetha N, Venkatachalam P, Rao GR (1998) In vitro plant regeneration from shoot tip culture of black gram (Vigna mungo L. Hepper). J Tropic Agric 36(1/2):6-11

18. Gulati A, Jaiwal PK (1990) Culture conditions effecting plant regeneration from cotyledon of mungbean [Vigna radiata (L.) Wilczek]. Plant Cell Rep 13:523-527

19. Polisetty R, Patil P, Deveshwar JJ, Khetarpal S, Suresh K, Chandra R (1997) Multiple shoot induction by benzyladenine and complete plant regeneration from seed explants of chickpea (Cicer arietinum L.). Plant Cell Rep 16:565-571

20. Vijayan S, Beena MR, Kirti PB (2006) Effective and simple regeneration of mungbean (Vigna radiata $(\mathrm{L})$. Wilzcek) using cotyledonary node explants. J Plant Biochem Biotechnol 15: 131-134

21. Das DK, Prasanna B, Prakash NS, Bhalla-Sarin N (2002) Improvement method of regeneration of black gram (Vigna mungo L.) through liquid culture. In Vitro Cell Dev Biol Plant 38(5):456-459 